\title{
Beta-thalassemia Major and Non-Hodgkin Lymphoma
}

Pusem Patir ${ }^{*}$, Nur Soyer and Guray Saydam

Department of Hematology, Ege University, Izmir, Turkey

*Corresponding author: Pusem Patir, Department of Hematology, Ege University, 35100 Bornova Izmir Turkey, Tel: +902323903540; Fax: +90-232-3903530; E-mail: pusemp@yahoo.com

Received date: May 09, 2016, Accepted date: May 12, 2016, Publication date: May 16, 2016

Copyright: ( 2016 Patir P, et al. This is an open-access article distributed under the terms of the Creative Commons Attribution License, which permits unrestricted use, distribution, and reproduction in any medium, provided the original author and source are credited.

Citation: Patir P, Soyer N, Saydam G (2016) Beta-thalassemia Major and Non-Hodgkin Lymphoma. J Blood Disord Transfus 7: 352. doi:10.4172/2155-9864.1000352

\begin{abstract}
Beta-thalassemia is a frequent genetic disorder in the Mediterranean area, presenting deficit of beta-globin chain synthesis, reduced hemoglobin in red blood cells. The occurence of lymphoma in thalassemia has rarely been reported. We hereby report a case of thalessemia major developing non-Hodgkin lymphoma.
\end{abstract}

Keywords: Beta-thalassemia major; Non-Hodgkin lymphoma

Beta-thalassemia is a frequent genetic disorder in the Mediterranean area, presenting deficit of beta-globin chain synthesis, reduced hemoglobin in red blood cells. The occurence of lymphoma in thalassemia has rarely been reported. We hereby report a case of thalessemia major developing non-Hodgkin lymphoma.

Our patient is a 30-year old woman diagnosed with betathalassemia major, treated with splenectomy at the age of 13 years, requiring transfusion with 2 units of packed red blood cells once every 2-3 weeks. Her ferritin level was $860 \mu \mathrm{g} / \mathrm{L}$. Her hemoglobin levels always ranged between 7.0 and $9.5 \mathrm{~g} / \mathrm{dL}$. She was maintained 30 $\mathrm{mg} / \mathrm{kg} /$ day deferasirox, single dose daily. Genetic analysis showed that she had mutation at $-30, \mathrm{~T}>\mathrm{A}$ heterozygous.

In May 2014, solid lymphadenopathies were detected in the left cervical at $3 \mathrm{~cm}$, right axillary at $2 \mathrm{~cm}$ and inguinal at $3 \mathrm{~cm}$ on examination of the patient. Simultaneous, sedimentation and Creactive protein were $109 \mathrm{~mm}$ and $4.8 \mathrm{mg} / \mathrm{dl}$, respectively. Antibiotic therapy was started but she did not respond to treatment. Thus axillary lymph node excision was performed in June 2014. The pathology revealed CD20-positive diffuse large B-cell lymphoma. Her LDH level was $748 \mathrm{mg} / \mathrm{dL}$. In positron emission tomography-computed tomography (PET-CT) showed that hypermetabolic cervical, supraclavicular, axillary, mediastinal and abdominopelvic lymph nodes. Bone marrow aspirate and biopsy were normal. The patient was evaluated as Stage IIIB and low-to-moderate risk, respectively, according to Ann-Arbor staging system and the international prognostic index. Lamivudine was initiated before chemotherapy, because of the patient with Hepatitis B virus carrier. In July 2014, she received the first cycles of rituximab, cyclophosphamide, doxorubicin, vincristin and prednisone (R-CHOP) chemotherapy. Chemotherapy on day 10 , she was admitted to the emergency because of fever, cardiac palpitations. On physical examination, she was hypotensive, tachycardic and had common oral mucositis. She had severe anemia (hemoglobin: $4.7 \mathrm{gr} / \mathrm{dl}$ ) in blood count but was not neutropenic. She received 4 units of packed red blood cells transfusion and antifungal and broad-spectrum antibiotic therapy were initiated. Her general condition improved during follow-up and she was discharged on. Her chemotherapy treatment was completed 6 cycles of R-CHOP and 2 cycles of $\mathrm{R}$ under close follow-up. The patient was followed with a complete remission. Her last CT of neck, thorax and abdomen were also negative.

The incidence of beta-thalassemia and hematological malignancies was up to $9.5 \%$ [1]. Survival and causes of death were evaluated in 1087 Italian patients with thalassaemia major and the death of eight patients with malignancy were reported [2]. This case report is intended to alert hematologists for the possibility of rapid, prolonged and severe anemia, may occur after chemotherapy in thalassemia major with non-Hodgkin lymphoma. Therefore, in these patients compared to other lymphoma patients more often need to assess blood count.

\section{Patient Consent}

Informed consent was obtained for publication of anonymized patient information.

\section{Conflict of Interest}

Authors declare no conflict of interests for this article.

\section{Author Contributions}

All authors equally contributed to this paper with conception and literature review, and critical revision and editing, and final approval of the final version.

\section{References}

1. Panich V, Na-Nakorn S, Piankijagum A (1974) Hemoglobinopathies and G6PD deficiency in lymphoma. J Med Assoc Thailand 57: 1-10.

2. Zurlo MG, De Stefano P, Borgna-Pignatti C, Di Palma A, Piga A, et al. (1989) Survival and causes of death in thalassaemia major. Lancet 2: 27-30. 